\title{
Physical properties of safflower grains. Part I: Geometric and gravimetric characteristics
}

\author{
Elton A. S. Martins ${ }^{1}$, André L. D. Goneli ${ }^{1}$, Cesar P. Hartmann Filho ${ }^{1}$, \\ Munir Mauad ${ }^{1}$, Valdiney C. Siqueira ${ }^{1} \&$ Alexandre A. Gonçalves ${ }^{1}$
}

${ }^{1}$ Universidade Federal da Grande Dourados/Faculdade de Ciências Agrárias. Dourados, MT. E-mail: elton_asm@hotmail.com (Corresponding author); andregoneli@ufgd.edu.br; cphartmann21@hotmail.com; munirmauad@ufgd.edu.br; vcambuy@yahoo.com; alexandre_alvesg@hotmail.com

Key words:

Carthamus tinctorius L.

bulk density

shape of grains

\begin{abstract}
A B S T R A C T
Safflower is an oil crop and its oil can be used for food and industrial purposes. However, there is little information about the physical properties of these grains, which is important for the planning and execution of post-harvest stages. Thus, this study was carried out with the aim of evaluating the effect of drying on the main physical properties of safflower grains. Safflower grains were harvested with an initial moisture content of approximately 0.445 decimal d.b. (dry basis) and subjected to drying in an oven with forced air circulation at 40 ${ }^{\circ} \mathrm{C}$, until the grains reached a final moisture content of $0.073 \pm 0.008$ decimal d.b. During the drying, bulk density and true density, porosity, thousand-grain mass, circularity, sphericity, projected and surface area, and surface-volume ratio were measured. Based on these results, it is concluded that all gravimetric and geometrical characteristics of safflower grains were reduced due to the reduction of moisture content, except for the surface-volume ratio.
\end{abstract}

\section{Palavras-chave:}

Cartamos tinctorius L. massa específica forma dos grãos

\section{Propriedades físicas dos grãos de cártamo. Parte I: Características geométricas e gravimétricas}

\begin{abstract}
R E S U M O
O cártamo é uma cultura oleaginosa cujo óleo pode ser utilizado para fins alimentícios e industriais, porém há poucas informações dessa cultura sobre alguns aspectos relevantes em seu sistema de produção, como as propriedades físicas dos grãos as quais são informações importantes para execução e planejamento das etapas de pós-colheita. Assim, o presente trabalho foi desenvolvido com o objetivo de avaliar o efeito da secagem sobre as principais propriedades físicas dos grãos de cártamo. Foram utilizados grãos de cártamo colhidos com teor de água inicial de aproximadamente 0,445 decimal b.s. (base seca) e submetidos à secagem em estufa com circulação forçada de ar, na temperatura de $40{ }^{\circ} \mathrm{C}$, até os grãos atingirem o teor de água final de 0,073 $\pm 0,008$ decimal b.s. Durante a secagem foram mensuradas a massa específica aparente e unitária, porosidade, massa de mil grãos, circularidade, esfericidade, área projetada e superficial e relação superfície volume. Com base nos resultados obtidos, conclui-se que todas as características gravimétricas e geométricas dos grãos de cártamo se reduzem em função da redução do teor de água com exceção da relação superfície volume.
\end{abstract}




\section{INTRODUCTION}

Safflower (Carthamus tinctorius L.), despite being a crop with little expression in the Brazilian agricultural scene, has great potential to be a very popular crop in Brazil, not only because its oil serves as raw material for biodiesel production, but also because of its various applications, such as food and industrial purposes (Ekin, 2005; Emongor, 2010), being also a crop with large capacity of development in different regions of Brazil. Another relevant factor for its success is that sowing, crop practices and harvest can be mechanized, without the need to acquire specific machines for the crop.

As most agricultural products, safflower is harvested with high moisture content to reduce losses and the attacks of insects and microorganisms at field; thus, it must be subjected to a drying process. Drying is a complex process involving the simultaneous transfer of heat and mass between the product and the air, resulting in significant changes in the chemical composition, structure and physical properties of the foods (Koç et al., 2008).

According to Goneli et al. (2011), physical and geometric properties, such as specific weight, size and volume, among other physical properties, are important information to project and dimension machines and equipment intended for the postharvest of agricultural products, as well as for studies involving the transfer of heat and mass and air movement in granular masses. Since safflower is a crop little studied in Brazil, the survey of these physical properties is relevant for the success of these grain post-harvest stages.

In this context, this study aimed to evaluate the main physical properties of safflower grains during the drying, such as bulk density, true density, porosity, thousand-grain mass, circularity, sphericity, projected and surface areas and surface-volume ratio.

\section{Material AND Methods}

The present study was carried out at the Laboratory of Pre-Processing and Storage of Agricultural Products of the Faculty of Agrarian Sciences - FCA, belonging to the Federal University of Grande Dourados - UFGD, in the municipality of Dourados, MS, Brazil, from August to September 2013.

Safflower grains cultivated at the UFGD Experimental Farm were used in the experiment. The safflower capitula were manually harvested, selecting only those that had already reached maturation. Threshing was manually performed, followed by a new selection, removing all defective grains to avoid any type of undesirable influence that might interfere with the research results.

After threshing, the safflower grains were placed in lowdensity plastic packages and stored in B.O.D chambers at temperature of $3.5^{\circ} \mathrm{C}$, to avoid water exchange in the form of vapor between the product and the external environment, in order to maintain and homogenize the moisture content of the product. The safflower grains showed an initial moisture content of approximately 0.445 decimal d.b. (dry basis).

The product was dried in a forced-air oven at the temperature of $40^{\circ} \mathrm{C}$, with the single purpose of reducing the moisture content of the grains. The reduction of moisture content for the bulk density determination was monitored using a scale with 0.01 -g resolution, while the other physical properties were monitored using a scale with $0.001-\mathrm{g}$ resolution, through the gravimetric method (mass loss), until the grains reached the final moisture content of $0.073 \pm 0.008$ decimal d.b. The initial and final moisture contents of safflower grains were determined by the gravimetric method in an oven at $105 \pm 1{ }^{\circ} \mathrm{C}$, for $24 \mathrm{~h}$, in two replicates (Brasil, 2009).

The bulk density $\left(\rho_{\text {ap }}\right)$, in $\mathrm{kg} \mathrm{m}^{-3}$, of the product was determined using a scale of hectoliter weight, with volume of $250 \mathrm{~mL}$. For each moisture content sampled during the drying, five measurements were taken, and the bulk density resulted from the mean of these five measurements.

The true density and other physical properties were determined by randomly selecting 18 individually dried safflower grains. For each moisture content sampled during the drying process, a digital caliper with resolution of $0.01 \mathrm{~mm}$ was used to measure the perpendicular diameters of the product (Figure 1), length (a), width (b) and thickness (c), all in mm.

The volume of each grain, along the drying process, was determined using Eq. 1, proposed by Jain \& Bal (1997), considering the form of the product as a conical-spherical body.

$$
\begin{gathered}
\mathrm{V}_{\mathrm{g}}=\frac{\pi \mathrm{D}^{2} \mathrm{a}^{2}}{6(2 \mathrm{a}-\mathrm{D})} \\
\mathrm{D}=(\mathrm{b} \times \mathrm{c})^{0.5}
\end{gathered}
$$

where:

$\mathrm{V}_{\mathrm{g}}$ - volume of the grain, $\mathrm{mm}^{3}$; and,

$\mathrm{D}$ - geometric mean of the measurements " $\mathrm{b}$ " and " $\mathrm{c}$ " of the product, $\mathrm{mm}$.

This equation to calculate the volume of the product was selected based on preliminary tests with toluene, in which the actual grain volume was compared with the volume calculated by equations presented in the literature, and the abovementioned equation led to the best estimate of grain volume.

The volume and mass of each grain $\left(\mathrm{m}_{\mathrm{g}}\right.$, in $\left.\mathrm{g}\right)$ were used to determine the true density $\left(\rho_{\mathrm{u}}\right.$, in $\left.\mathrm{kg} \mathrm{m}^{-3}\right)$ through Eq. 3, and the porosity $(\varepsilon$, in \%;) of the mass of safflower grains was indirectly determined through Eq. 4.

$$
\begin{gathered}
\rho_{\mathrm{u}}=\frac{\mathrm{m}_{\mathrm{g}}}{\mathrm{V}_{\mathrm{g}}} 10^{6} \\
\varepsilon=\left(1-\frac{\rho_{\text {ap }}}{\rho_{\mathrm{u}}}\right) 100
\end{gathered}
$$
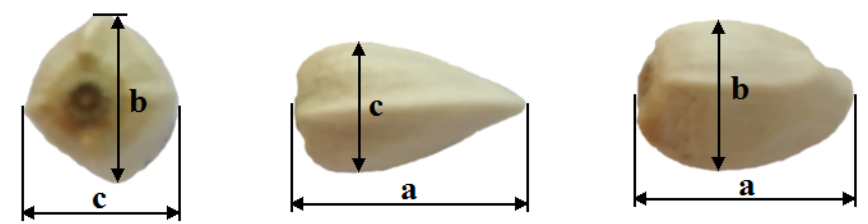

Figure 1. Representation of the perpendicular diameters of the safflower grains 
The thousand-grain mass was determined according to the Norms of Seed Analysis (Brasil, 2009), by randomly selecting 100 grains, in eight replicates, to determine the mass of each replicate using a scale with $0.001 \mathrm{~g}$ resolution. The results obtained for each moisture content sampled during the drying were adjusted to 1000 grains.

The sphericity $\left(\mathrm{E}_{\mathrm{s}}\right)$, in \%, of the grains was calculated according to Eq. 5, following the methodology also used by Zewdu \& Solomon (2007). The circularity (C), in \%, of the grains was determined through Eq. 7 (Moshenin, 1986).

$$
\begin{aligned}
\mathrm{E}_{\mathrm{s}} & =\frac{\mathrm{D}_{\mathrm{e}}}{\mathrm{D}_{\mathrm{c}}} 100 \\
\mathrm{D}_{\mathrm{e}} & =\sqrt[3]{\frac{6 \mathrm{~V}_{\mathrm{g}}}{\pi}} \\
\mathrm{C} & =\frac{\mathrm{b}}{\mathrm{a}} 100
\end{aligned}
$$

where:

$\mathrm{D}_{\mathrm{e}} \quad$ - diameter of the equivalent sphere, $\mathrm{mm}$; and,

$\mathrm{D}_{c}$ - diameter of the smallest circumscribed sphere (greatest dimension of the product), $\mathrm{mm}$.

The projected area $\left(A_{p}\right)$, in $\mathrm{mm}^{2}$, of the safflower grains was determined using Eq. 8, while the surface area (S), in $\mathrm{mm}^{2}$, was determined through the method described by Mohsenin (1986), Eq. 9, in which the characteristic dimensions of the product are adjusted.

$$
\begin{gathered}
\mathrm{A}_{\mathrm{p}}=\frac{\pi \mathrm{ab}}{4} \\
\mathrm{~S}=\frac{\pi \mathrm{D}^{2}}{2}+\frac{\pi \mathrm{aD}}{2 \mathrm{e}} \sin ^{-1} \mathrm{e} \\
\mathrm{e}=\sqrt{1-\left(\frac{\mathrm{D}}{\mathrm{a}}\right)^{2}}
\end{gathered}
$$

where:

e - eccentricity.

The ratio between the surface area and volume of safflower grains (SV), in $\mathrm{mm}^{-1}$, was determined through Eq. 11.

$$
\mathrm{SV}=\frac{\mathrm{S}}{\mathrm{V}_{\mathrm{g}}}
$$

The experimental data relative to the bulk density, true density, thousand-grain mass, porosity and the analysis of the form and size of safflower grains were subjected to linear regression analysis. Regression models were fitted using the computer program SigmaPlot 11.0, based on the selection criteria of significance level of the model by $\mathrm{F}$ test and the coefficient of determination $\left(\mathrm{R}^{2}\right)$.

\section{Results AND Discussion}

The values of bulk density decreased with the reduction in the moisture content of the safflower grains (Figure 2A), but agricultural products usually have the opposite trend for this property (Milani et al., 2007; Resende et al., 2008; Tavakoli et al., 2009; Seifi \& Alimardani, 2010a; Jesus et al., 2013). However, Seifi et al. (2010), working with safflower grains, variety Goldasht, found a similar trend to that found in the present study, as already observed for other crops, such as jatropha seeds (Siqueira et al., 2012a), melon seeds (Bande et al., 2012) and pistachio grains (Razavi et al., 2007).

Araújo et al. (2014) also observed a similar trend for the bulk density of peanut grains, cultivar IAC 505, from the vegetative and commercial group Runner, whose values decreased along the drying. These authors attributed this effect to a greater contraction of the internal part of the cotyledons of the product in relation to its external dimensions, which contract in lower proportion, forming empty spaces inside the grain, which was evidenced after the coat envolving the grains was removed. This same effect was observed in the present study (Figure 3), in which the safflower grains were

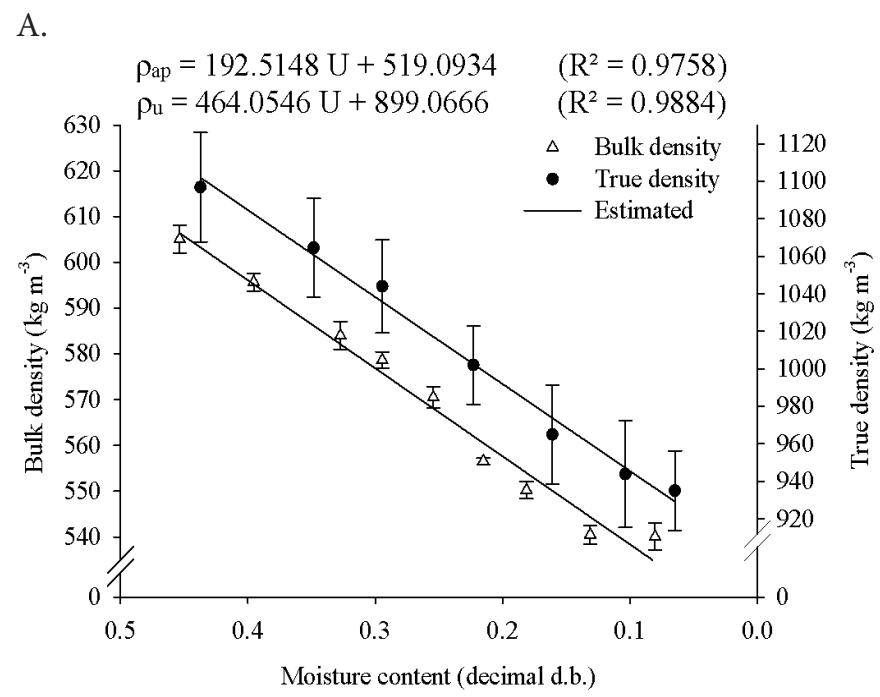

B.

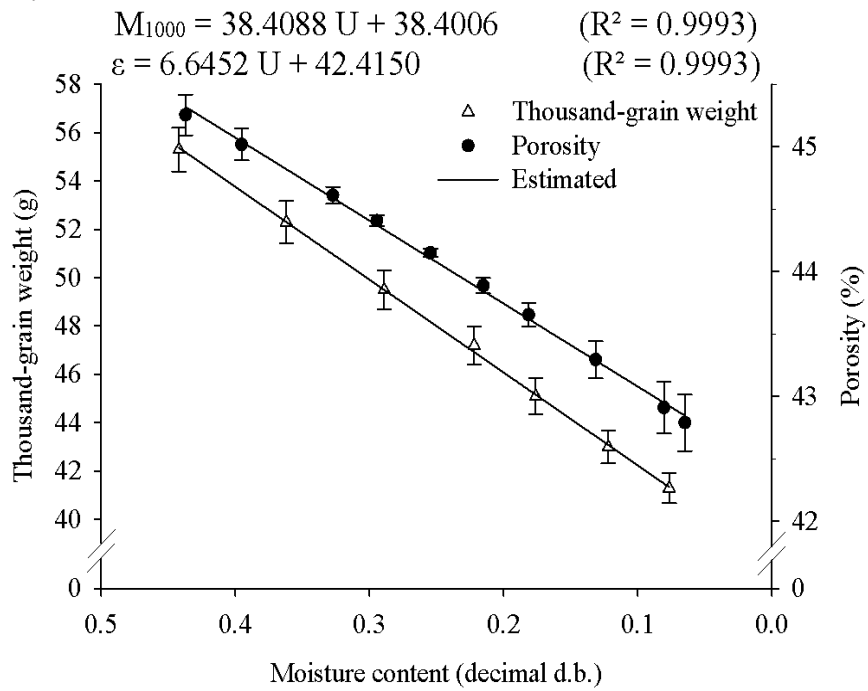

Figure 2. Observed and estimated values of bulk density (A), thousand-grain mass and porosity (B) of safflower grains as a function of the moisture content 

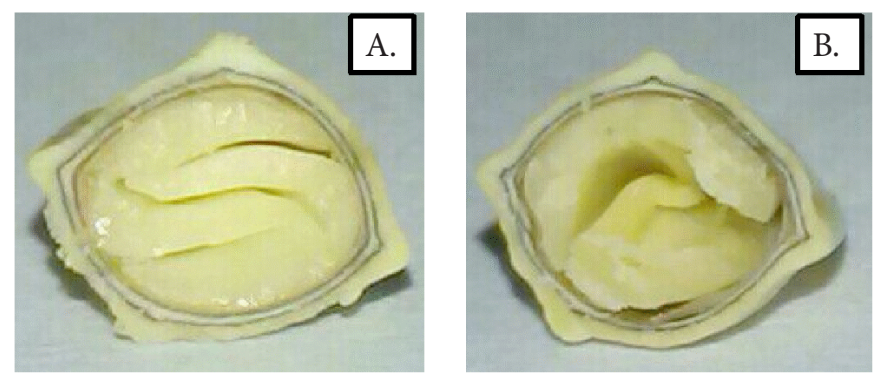

Figure 3. Safflower grain before drying (A) and after drying (B)

cut before the drying $(\mathrm{U} \approx 0.445$ decimal d.b.) and after drying $(\mathrm{U} \approx 0.073$ decimal d.b. $)$.

The safflower grains significantly reduced the endosperm during the drying (Figure 3), also reducing the mass of the product, while the external part of the grain did not reduce in the same proportion as the internal part. Hence, the specific weight decreases along the drying, because it is a ratio between the mass and volume of the product. The lower reduction of the volume in comparison to its mass can also be attributed to the resistance of the tegument of the grains of this crop to contraction.

The values of bulk density varied from 605.03 to 540.06 $\mathrm{kg} \mathrm{m}^{-3}$ (Figure 2A), for a moisture content range from 0.45 to 0.08 decimal d.b., respectively, and these values were satisfactorily represented by a linear regression model.

The values of the true density of safflower grains decreased along the drying (Figure 2A), evidencing that the reduction in grain volume during the drying was less intense than the reduction of its mass, as already explained and illustrated in Figure 3, for the bulk density. Thus, the true density of safflower grains showed a trend similar to that of the bulk density. A similar trend to that of the present study for the true density has also been found for other species, such as for seeds of cucurbits (Milani et al., 2007), jatropha (Siqueira et al., 2012a), grains of pistachio (Razavi et al., 2007) and peanut (Araujo et al., 2014).

The true density of safflower grains (Figure 2A) varied from 1096.88 to $934.95 \mathrm{~kg} \mathrm{~m}^{-3}$ for the moisture content range from 0.44 to 0.06 decimal d.b., respectively, and the relationship between these two variables was represented by a linear regression model.

The porosity values of the safflower grain mass decreased along the drying (Figure 2B), a common trend for many agricultural products (Isik \& Izli, 2007; Zewdu \& Solomon, 2007; Resende et al., 2008; Seifi \& Alimardani, 2010b; Siqueira et al., 2012a). This trend can be explained, because agricultural products have, as a characteristic with the reduction of the moisture content, the reduction of their volume, causing the mass of the product to compact, reducing the intergranular spaces.

Seifi et al. (2010), evaluating the porosity of safflower grain mass, variety Goldasht, observed the opposite trend to that found in the present study, in which the porosity of the mass decreased from 51.40 to $45.84 \%$, during a rewetting process in which the moisture content varied from 0.04 to 0.28 decimal d.b., while in the present study the porosity reduced from 45.25 to $42.79 \%$ for the moisture content range from 0.44 to 0.06 decimal d.b. (Figure 2B). The relationship between these two variables is satisfactorily represented by a linear regression model, showing high significance.

The safflower grain mass reduces as its moisture content decreases (Figure 2B), a trend that is expected for any agricultural product during the drying. The drying process removes part of the water bound to the agricultural products, causing their mass to decrease.

Seifi et al. (2010) observed that the thousand-grain mass of the safflower variety Goldasht varied from 50.50 to $59.20 \mathrm{~g}$ for a moisture content range from 0.04 to 0.28 decimal d.b., while in the present study it varied from 55.30 to $41.30 \mathrm{~g}$ for a moisture content range from 0.44 to 0.07 decimal d.b., and this phenomenon was represented by a linear regression model, with high values of coefficient of determination and significance level of the regression.

The circularity of safflower grains decreased by approximately $2.0 \%$ for the studied moisture range (Table 1). The low reduction in the circularity values evidences the low reduction in the width and length of the safflower grains, and the circularity obtained in the present study (Eq. 7) is a ratio between these two dimensions of the grain. The greater reduction in the width axis in comparison to the length caused a decrease in the circularity of safflower grains during the drying. A similar trend of circularity was observed by Siqueira et al. (2012b) in jatropha fruits and by Goneli et al. (2011) in castor bean fruits.

The sphericity showed similar trend to that for the circularity of safflower grains, whose values reduced by approximately $1.6 \%$ (from 66.03 to $64.43 \%$ ), for a moisture content range from 0.44 to 0.06 decimal d.b. (Table 1). With the rewetting of safflower grains, evaluating the sphericity of the varieties Darab and Goldasht, Tarighi et al. (2011) observed that the sphericity values varied from 60 to $63 \%$ and from 66 to $68 \%$, respectively, for a moisture content range from 0.04 to 0.28 decimal d.b., which agree with the sphericity values found in the present study (Table 1).

A similar trend for the sphericity during the drying has also been reported for other species, such as peanut grains (Araujo et al., 2014), jatropha fruits (Siqueira et al., 2012b) and castor bean fruits (Goneli et al., 2011). The circularity and sphericity of safflower grains showed values below $70 \%$ and cannot be classified as either circular or spherical.

The projected area of safflower grains decreased from 29.39 to $27.32 \mathrm{~mm}^{2}$ with the reduction in moisture content from 0.44 to 0.06 decimal d.b. (Figure $4 \mathrm{~A}$ ), and this relationship was satisfactorily described by a linear regression model. This trend can be explained by the fact that safflower grains suffer

Table 1. Characteristic dimensions (a, b, c), circularity (C) and sphericity $\left(E_{s}\right)$ of safflower grains as a function of the moisture content

\begin{tabular}{cccccccc}
\hline $\begin{array}{c}\text { Moisture content } \\
\text { (decimal d.b.) }\end{array}$ & \multicolumn{3}{c}{ Dimensions (mm) } & & $\mathbf{C}$ & $\mathbf{E}_{\mathbf{s}}$ \\
\cline { 2 - 5 } \cline { 6 - 7 } & $\mathbf{a}$ & $\mathbf{b}$ & $\mathbf{C}$ & & \multicolumn{2}{c}{ (\%) } \\
0.44 & 7.35 & 5.09 & 4.19 & & 69.26 & 66.03 \\
0.35 & 7.30 & 5.04 & 4.13 & & 68.99 & 65.71 \\
0.29 & 7.28 & 5.00 & 4.10 & & 68.68 & 65.44 \\
0.22 & 7.26 & 4.97 & 4.08 & & 68.52 & 65.34 \\
0.16 & 7.24 & 4.95 & 4.05 & & 68.31 & 65.17 \\
0.10 & 7.21 & 4.89 & 4.01 & & 67.82 & 64.81 \\
0.06 & 7.19 & 4.84 & 3.97 & 67.28 & 64.43 \\
\hline
\end{tabular}


reduction in their characteristic dimensions during the drying process (Table 1). The reduction in the projected area during the drying for agricultural products has been observed by many authors for various products (Dursun et al., 2007; Guedes et al., 2011; Siqueira et al., 2012b; Araujo et al., 2014).

The surface area of safflower grains decreased along the drying process, as illustrated in Figure 4A, a trend also observed for peanut grains (Araujo et al., 2014), jatropha fruits (Siqueira et al., 2012b), melon seeds (Bande et al., 2012) and rice grains (Kibar et al., 2010).

The values of surface area (Figure 4A) varied from 94.63 to $87.36 \mathrm{~mm}^{2}$ for a moisture content range from 0.44 to 0.06 decimal d.b., and this relationship was described by a linear regression model, with high coefficient of determination.

The surface-volume ratios increased as the moisture content decreased in the safflower grains (Figure 4B), and the interaction between these variables during the drying process was satisfactorily described by a linear regression model. Araújo et al. (2014) and Siqueira et al. (2012b), working with peanut grains and jatropha fruits, respectively, also observed a similar trend for the surface-volume ratio during the drying.

A.

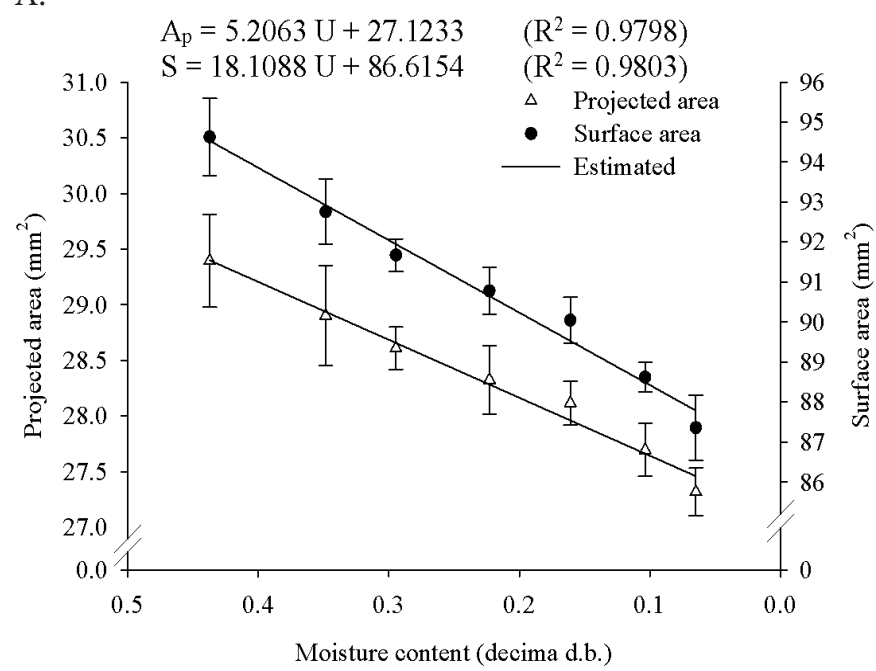

B.

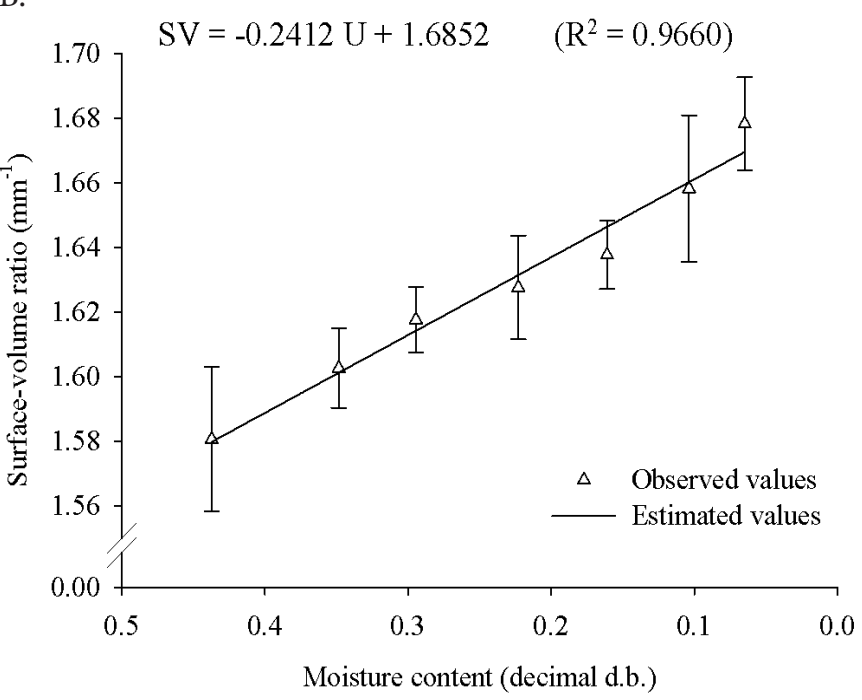

Figure 4. Observed and estimated values of projected and surface area (A) and surface-volume ratio (B) of safflower grains as a function of the moisture content
According to Farinha (2008), if only physical factors are involved in the process, the reduction rate in the moisture content is proportional to the surface-volume ratio (specific surface). Assuming that the form of the product is constant, the surface-volume ratio or specific surface of the product increases with the reduction in its volume, favoring the removal of water.

\section{Conclusions}

1. The reduction in moisture content during the drying causes reduction in the bulk density, true density, thousandgrain mass, circularity, sphericity and projected and surface areas.

2. With the reduction in moisture content, there is an increase in the values of the surface-volume ratio of safflower grains.

\section{ACKnowledgments}

The authors thank the Foundation to Support the Development of Education, Science and Technology of the State of Mato Grosso do Sul - FUNDECT and the Coordination for the Improvement of Higher Education Personnel - CAPES for the financial support for the development and dissemination of this work.

\section{Literature Cited}

Araujo, W. D.; Goneli, A. L. D.; Souza, C. M. A.; Gonçalves, A. A.; Vilhasanti, H. C. B. Propriedades físicas dos grãos de amendoim durante a secagem. Revista Brasileira de Engenharia Agrícola e Ambiental, v.18, p.279-286, 2014. https://doi.org/10.1590/S141543662014000300006

Bande, Y. M.; Adam, N. M.; Azmi, Y.; Jamarei, O. Moisture-dependent physical and compression properties of bitter melon (Citrullus colocynthis lanatus) seeds. International Journal of Agricultural Research, v.7, p.243-254, 2012. https://doi.org/10.3923/ ijar.2012.243.254

Brasil. Ministério da Agricultura, Pecuária e Abastecimento. Secretaria de Defesa Agropecuária. Regras para análise de sementes. Brasília: MAPA, 2009. 395p.

Dursun, I.; Tugrul, K. M.; Dursun, E. Some physical properties of sugarbeet seed. Journal of Stored Products Research, v.43, p.149155, 2007. https://doi.org/10.1016/j.jspr.2006.03.001

Ekin, Z. Resurgence of safflower (Carthamus tinctorius L.) utilization: A global view. Journal of Agronomy, v.4, p.83-87, 2005. https:// doi.org/10.3923/ja.2005.83.87

Emongor, V. Safflower (Carthamus tinctorius L.) the underutilized and neglected crop: A review. Asian Journal of Plant Sciences, v.9, p.299-306, 2010. https://doi.org/10.3923/ajps.2010.299.306

Farinha, L. R. L. Características físicas na perda da matéria fresca e evolução das propriedades reológicas e cor da cenoura cv. Brasília no armazenamento. Viçosa: UFV, 2008. 111p. Dissertação Mestrado

Goneli, A. L. D.; Corrêa, P. C.; Magalhães, F. E. A.; Baptestini, F. M. Contração volumétrica e forma dos frutos de mamona durante a secagem. Acta Scientiarum. Agronomy, v.33, p.1-8, 2011. https:// doi.org/10.4025/actasciagron.v33i1.4629 
Guedes, M. A; Mata, M. E. R. M. C.; Duarte, M. E. M.; Farias, P. A. Caracterização física de grãos de soja utilizando-se processamento digital de imagens. Revista Brasileira de Produtos Agroindustriais, v.13, p.279-294, 2011. https://doi.org/10.15871/1517-8595/rbpa. v13n3p279-294

Isik, E.; Izli N. Physical properties of sunflower seeds (Helianthus annuus L.). International Journal of Agricultural Research, v.2, p.677-686, 2007. https://doi.org/10.3923/ijar.2007.677.686

Jain, R. K.; Bal, S. Properties of pearl millet. Journal of Agricultural Engineering Research, v.66, p.85-91, 1997. https://doi.org/10.1006/ jaer.1996.0119

Jesus, F. F.; Souza, R. T. G.; Teixeira, G. C. S.; Teixeira, I. R.; Devilla, I. A. Propriedades físicas de sementes de feijão em função de teores de água. Engenharia na Agricultura, v.21, p.9-18, 2013. https:// doi.org/10.13083/1414-3984.v21n01a01

Kibar, H.; Öztürk, T.; Esen, B. The effect of moisture content on physical and mechanical properties of rice (Oryza sativa L.). Spanish Journal of Agricultural Research, v.8, p.741-749, 2010. https://doi.org/10.5424/sjar/2010083-1273

Koç, B.; Eren, I.; Ertekin, F. K. Modelling bulk density, porosity and shrinkage of quince during drying: The effect of drying method. Journal of Food Engineering, v.85, p.340-349, 2008. https://doi. org/10.1016/j.jfoodeng.2007.07.030

Milani, E.; Seyed, M.; Razavi, A.; Koocheki, A.; Nikzadeh, V.; Vahedi, N.; Moeinfard, M.; Gholamhosseinpour, A. Moisture dependent physical properties of cucurbit seeds. International Agrophysics, v.21, p.157-168, 2007.

Moshenin, N. N. Physical properties of plant and animal materials. New York: Gordon and Breach Publishers, 1986. 841p.

Razavi, S. M. A.; Rafe, A.; Moghaddam, T. M.; Amini, A. M. Physical properties of pistachio nut and its kernel as a function of moisture content and variety. Part II. Gravimetrical properties. Journal of Food Engineering, v.81, p.218-225, 2007. https://doi. org/10.1016/j.jfoodeng.2006.10.024
Resende, O.; Corrêa, P. C.; Goneli, A. L. D.; Ribeiro, D. M. Propriedades físicas do feijão durante a secagem: Determinação e modelagem. Ciência e Agrotecnologia, v.32, p.225-230, 2008. https://doi.org/10.1590/S1413-70542008000100033

Seifi, M. R.; Alimardani, R. Moisture-dependent physical properties of sunflower seed (SHF8190). Modern Applied Science, v.4, p.135143, 2010a. https://doi.org/10.5539/mas.v4n7p135

Seifi, M. R.; Alimardani, R. Comparison of moisture-dependent physical and mechanical properties of two varieties of corn (Sc 704 and Dc 370). Australian Journal of Agricultural Engineering, v.1, p.170-178, 2010b.

Seifi, M. R.; Alimardani, R.; Akram, A.; Asakereh, A. Moisture-depend physical properties of safflower (Goldasht). Advance Journal of Food Science and Technology, v.2, p.340-345, 2010.

Siqueira, V. C.; Resende, O.; Chaves, T. H. Propriedades físicas das sementes de pinhão-manso ao longo da secagem em diferentes temperaturas. Semina: Ciências Agrárias, v.33, p.2705-2714, 2012a. https://doi.org/10.5433/1679-0359.2012v33Supl1p2705

Siqueira, V. C.; Resende, O.; Chaves, T. H.; Soares, F. A. L. Forma e tamanho dos frutos de pinhão-manso durante a secagem em cinco condições de ar. Revista Brasileira de Engenharia Agrícola e Ambiental, v.16, p.864-870, 2012b. https://doi.org/10.1590/ S1415-43662012000800008

Tarighi, J.; Mahmoudi, A.; Rad, M. K. Moisture-depend some postharvest properties of two varieties of safflower (Darab and Goldasht). Modern Applied Science, v.5, p.139-148, 2011. https:// doi.org/10.5539/mas.v5n1p139

Tavakoli, M.; Tavakoli, H.; Rajabipour, A.; Ahmadi, H.; GharibZahedi, S. M. T. Moisture-dependent physical properties of barley grains. International Journal of Agricultural and Biological Engineering, v.2, p.84-91, 2009.

Zewdu, A. D.; Solomon, W. K. Moisture-dependent physical properties of tef seed. Biosystems Engineering, v.96, p.57-63, 2007. https:// doi.org/10.1016/j.biosystemseng.2006.09.008 